\title{
The Method and Algorithm \\ for Providing Information Exchange \\ in a Complex Hierarchical Management System \\ in Terms of Information Overload
}

\author{
Mikhail V. Semin* \\ Military Training and Research Center of the Air Force \\ «Air Force Academy ft. Professor N.E. Zhukovsky and Y.A. Gagarin» \\ 5 a Starykh Bol'shevikov Str., Voronezh, 394064, Russia
}

Received 25.02.2016, received in revised form 20.03.2016, accepted 18.04.2016

The task of developing a method and information presentation algorithm for the exchange of complex hierarchical management system in terms of information overload. The criteria of inclusion of information aggregation algorithm. Finding of fact overload the system asked to carry out by comparing the distances between aircraft objects with preset thresholds, the amount of air objects in the processing system of the automated control system components and for each region of space, covert interference - the operator of the complex automation.

Keywords: automated control system, information overload, air facility, the complex of automation, data aggregation, data transmission.

Citation: Semin M.V. The method and algorithm for providing information exchange in a complex hierarchical management system in terms of information overload, J. Sib. Fed. Univ. Eng. technol., 2016, 9(4), 470-480. DOI: $10.17516 / 1999-494 X-2016-9-4-470-480$.

(C) Siberian Federal University. All rights reserved

* Corresponding author E-mail address: anpotapov36@yandex.ru 


\title{
Метод и алгоритм представления информации
}

\section{для обмена в сложной иерархической}

автоматизированной системе управления

в условиях информационной перегрузки

М.В. Семин

ВУНЦ ВВС «ВВА им. проф. Н.Е. Жуковского и Ю.А. Гагарина»

Россия, 371600, Воронеж, ул. Старых Большевиков, $54 a$

\begin{abstract}
Рассмотрена задача разработки метода и алгоритма представления информации для обмена в сложной иерархической автоматизированной системе управления в условиях информационной перегрузки. Определень критерии включения алгоритма агрегирования информации. Обнаружение факта перегрузки системы предложено осуществлять путём сравнения расстояний между воздушными объектами с заданными порогами, количества воздушных объектов, находящихся в системе обработки элемента автоматизированной системы управления и по каждой области пространства, прикрытой помехами-оператором комплекса средств автоматизации.
\end{abstract}

Ключевые слова: автоматизированная система управления, информационная перегрузка, воздушный объект, комплекс средств автоматизации, агрегирование информации, передача данных.

\section{Introduction}

Reporting method for the exchange of information in a complex hierarchical system of automated control system (ACS) is intended to harmonize the amount of incoming information with the limited possibilities of information transmission channels and consumer computer systems for receiving and processing information. It should provide an idea of a large amount of information less, and, if necessary, to restore the previous amount of information at the receiving end (in the computer system user information) with the quality to meet customer requirements.

State information overload typical for conditions of massive strikes and dense fighting orders. In these circumstances, when processing can form a large number of false paths, which creates prerequisites for computing the consumer information overload of the complex, as well as channels and processing stations that receive information from the consumer. Therefore, the method is also designed to minimize processing errors, creating prerequisites for information overload in the system as a whole [1].

If the characteristics match incoming information system capabilities, the system functioning traditional algorithms. The algorithm should be included only in conditions when the conditions are created for information overload.

\section{Overload detection algorithm}

To implement the procedure information overload detection system must determine the attributes on which it can be identified in the system and criteria for inclusion aggregation algorithm.

The signs, which is identified with the overload of the system, is the amount of data on air situation (marks from air objects) and quality of information [2]. 
Where the number of marks on the air objects, values comparable to or higher than the performance of the channel and the consumer, there is a situation of information overload, increase the delay of information, reduces the quality (accuracy and reliability).

The quality of information deteriorates significantly in a dense and combat formations when the distance between the objects in the group of comparable size and fewer gates used in the treatment (secondary and tertiary). This one gets a few gate marks from the aircraft objects and is formed of a large number of false paths, which creates prerequisites for information overload.

These factors indicate the need for information aggregation and, accordingly, its representation in each group or spatially extended (interference area) Air object aggregated feature (one member) in order to minimize errors occurring during further processing into complex hierarchical ACS [3].

We define the criteria for inclusion of aggregation algorithm.

Aggregation of can be performed on a specific object or group to air on all of the information issued in the exchange channel.

As a criterion for the inclusion of aggregation algorithm for a particular group of markers is proposed a criterion based on a comparison of the distance between objects in the air group and a predetermined threshold corresponding to the size of the gate processing

$$
K_{1} \Rightarrow\left\{\begin{array}{l}
\Delta D_{(i ; i+1), t} \leq \delta_{\text {coпр. } X Y}, \\
\Delta H_{(i ; i+1), t} \leq \delta_{\text {coпр. } H},
\end{array}\right.
$$

where $\Delta D_{(i ; i+1), t}, \Delta H_{(i ; i+1), t}-$ distance between $i$ and (i+1) air objects (AO) в $t$-ом processing cycle; $\delta_{\text {сопр.XY, }}$ $\delta_{\text {conp.H }}$ - Strobe support for planar coordinates and altitude.

As an indication that the preconditions for the emergence of information overload channel or the consumer and the need to aggregate all the information issued from this source, it is proposed to use a number of marks on the air objects, commensurate with the channel capacity or the consumer.

Inclusion criteria issued in exchange channel aggregation algorithm on the entire amount of information K2yavlyayutsya achievement marks of air targets certain amount commensurate with the marginal productivity of the system element

$$
K_{2} \Rightarrow J \geq k_{2} M_{\max }
$$

where $J$ - total number of AO, are on machining; $M_{\max }$ - Maximum performance of channel (AC); $k_{2}$ - coefficient determining the permissible load on the aircraft number of channels.

For the detection of an overload on the number of transmitted channels codified standard used criterion

$$
K_{3} \Rightarrow N \geq k_{3} N_{\max }
$$

where $N, N_{\max }$ - number formed for transmission standard codified in this cycle sharing channel and performance by the number of codified transmitted, respectively; $k_{3}$ - coefficient determining the permissible load on the number of channels transmitted codified standard.

Overload detection algorithm is composed of blocks of tests $K_{1}, K_{2}, K_{3}$, is shown in Fig. 1.

In operation of the algorithm in the case of fulfillment of the criteria suggested above $K_{1,2,3}=1$. It is integrating and aggregating algorithm selection method of presentation of aggregated data. 


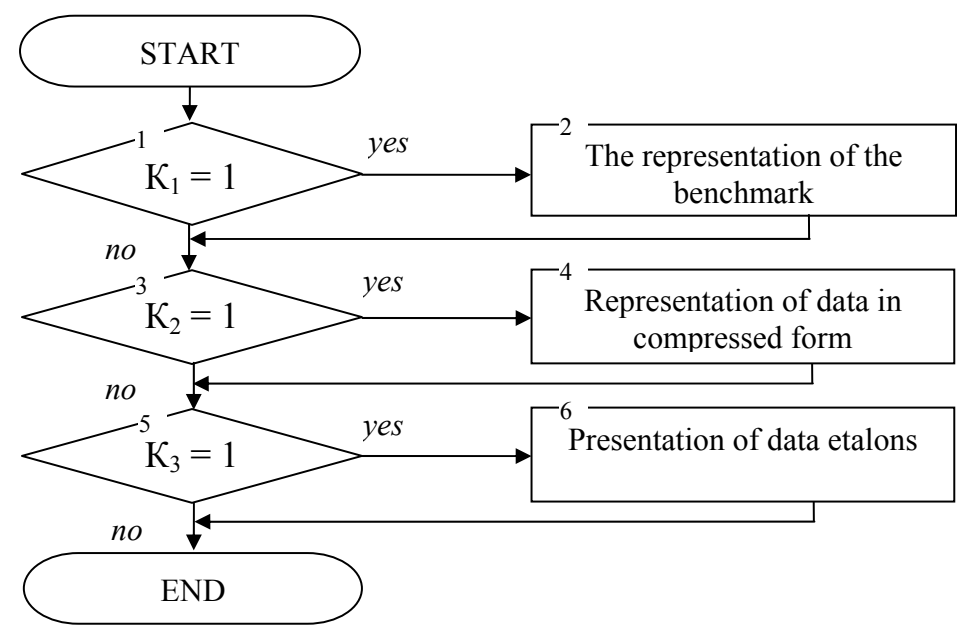

Fig. 1. Overload detection algorithm

Criterion $K_{1}$ It is determined for each group of criteria $K_{2}, K_{3}$ - for all information.

In the case of the selected criteria in the channel are given information about the selected algorithm aggregation features that characterize the group or spatially extended objects in the air and generally summarized their characteristics.

In applying the enemy jamming the main feature is the appearance of areas of uncompensated debris. Determining the need for aggregation and transmission of aggregated information on each, covert interference specific area of airspace, carried out by the operator of the complex automation equipment (CAE). The operator indicates the area veiled interference set of points on the outer boundary of the area in places of the highest intensity. Thus, the information as a group of air facilities, and areas of interference generated in a standard form suitable for aggregation and presentation to share [4].

In addition, depending on customer requirements to the degree of detail on the components of the group, it may be issued in a partially summarized or aggregated form. If an air group object is outside the zone of active agents aggregated data are given in summary form. If the air is subject to the active means of action zone and it solves the problem of target distribution, aggregated data are given in summary form. In solving the problem of targeting is necessary to pass on the issue of data in a partially summarized, and the degree of generalization is determined loading data channel [5].

Thus, the findings of an overload of the system is proposed to carry out by comparing the distances between aircraft objects with preset thresholds, the number of $\mathrm{AO}$ in the circuit processing element ACS and each region of space, covert interference - CAE operator.

\section{Aggregation of information on the traffic situation for the issuance of a data channel}

In accordance with the structure of abstract elementary subsystem requirements for the submission method, the method of appointment of its presentation should consist of algorithms for detecting information system overload, the actual provision of information for the exchange, processing and recovery of information about the traffic situation on the receiving end (Fig. 2). 


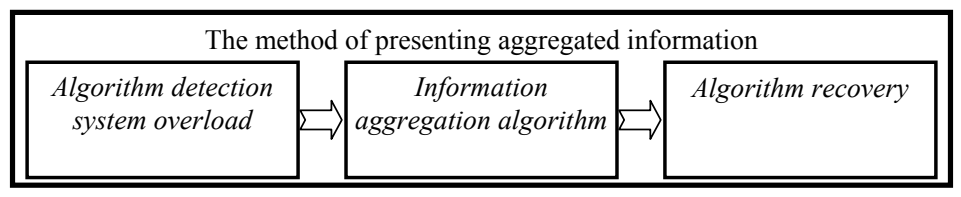

Fig. 2. The structure of the method of presentation of aggregated information on the traffic situation for the issuance of a data channel

Suppose that in the zone of responsibility of information subsystem complex hierarchical CAE is a fragment of a massive strike, consisting of several dense groups AO. We describe the set of this fragment $X$, then $X_{k}$ - subset $k$-ой groups, $k=[1, K]$, and $x(v, p, t) \in X_{k} \subseteq X$ - an element of this subset, t. e. a separate air facility, which is characterized by certain kinematic parameters and characteristics.

Measuring tools perform the detection and identification of the origin and features air objects. Then, in the processing the item processing system provides data on air situation forms a subset of markers from the air objects

$$
X_{R}=X \times R_{S}
$$

and

$$
X \rightarrow X_{R}, \text { then } X_{k} \rightarrow X_{k R}, k=[1, K] \text { or } \bigcup_{N_{1}} x_{n R}(v, p, t) \subseteq X_{R}, \bigcup_{K} X_{k} \subseteq X_{R} .
$$

It is necessary to develop a method of aggregating information on the traffic situation, providing the minimization of information loss in the unit, an abstract system of complex hierarchical CAE in terms of information overload

$$
a(A)=(1-K), a \rightarrow \min
$$

while meeting the requirements of information users to its quality, that is, to develop a method $A$

$$
A \in A^{0} .
$$

As shown above, the basic requirement for such a method of aggregating information is to provide a selection of subsets of groups, despite the fact that their intersection is the empty set of

$$
A\left\{X_{R}\right\}=\bigcup_{K} X_{k R}, \quad \forall \bigcap_{k} X_{k R}=\varnothing, A \in A_{\Theta} .
$$

Due to the vagueness of the information about the groups stamp of air objects, formally it is possible to describe a fuzzy subset of the universal set X. A fuzzy subset of markers group is a collection of pairs

$$
X_{k R}=\left\{\left(x_{R}, \mu\left(x_{R}\right)\right)\right\} .
$$

If $\mu_{1}\left(x_{R 1}\right)$ membership function, which characterizes the degree of belonging AO group (the general problem to be solved by the group), then it must be non-zero for objects belonging to the same group, and zero for objects belonging to different groups

$$
-474-
$$




$$
\mu\left(x_{R}\right)=\left\{\begin{array}{l}
{\left[\beta_{R}, 1\right], \beta>0, \forall x_{R} \in X_{k R},} \\
0, \quad \forall \mathrm{x}_{\mathrm{R}} \notin X_{k R} .
\end{array}\right.
$$

At the same time, in aggregation should stand out features that characterize a group of air objects in general. To develop the method of aggregation that satisfies the requirements described earlier is necessary to consider the properties of the relationship as the relationship R characterizing the group as a whole marks.

Why analyze the properties of the membership function in the conditions of influence characteristic of the process air situation display system uncertainty. Function accessories must be calculated in such a way that the degree of ownership of objects of different groups was equal to zero, which corresponds to the maintenance requirements of emptiness groups subsets of the intersection subset.

As a result of uncertainty in the displaying of air situation in the information subsystem (detection and treatment) on the point, provides data on air situation, each element of the original universal set $\mathrm{X}$ can be mapped in the system in the form of a fuzzy subset, which is consistent with the actual situation of false marks and trajectories.

When the calculations take into account that

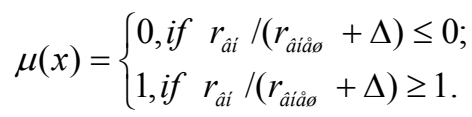

In accordance with the requirements for aggregation method, in order to minimize errors crossing subset becomes an empty when

$$
\mu(x)=\min \{\mu(x)\}=0 .
$$

This means that the function of the object accessories, is a component of one group to any other group entity must be equal 0 .

If the air object uniquely belongs to the fuzzy set group, the membership function takes a value equal to 1 .

Each of the air objects described by the following set of data:

- coordinates $x, y, h$ in a rectangular coordinate system;

- velocity components $v_{x}, v_{y}, v_{h}$;

- indicative information, which may include about 70 different signs in accordance with [6]. The main ones are the basis of nationality ("own", "alien", "unidentified"), object index of air

(7 gradations), a sign of the action of active agents against air targets, the type of aircraft object (an order of 200 gradations types of aircraft).

In the context of such a variety of information that characterizes the elements of the air situation is necessary to aggregate data about the traffic situation, that is, to form classes of equivalent or similar aerial objects or tactical groups.

Aggregation of information is used for the uniform, directly disparate objects. Therefore, aggregation is necessary to consider all the symptoms, but rather to consider their consistency in terms of the possibility of incorporating into a single group.

AO equivalence of separate in terms of the kinematic parameters will be considered appropriate to their proximity to the coordinates and speed characteristics. Sign information is 
used as specified for the decision to classify each individual object to the appropriate group. For objects that belong to one group, it should not be contradictory. For example, one group can not include objects that have signs state affiliation "their" and "foreign", as they decide to quite the opposite problem.

As shown above the main characteristic of the displayed data is the uncertainty in the nature of vagueness. Due to the presence and extensive though population, but indirect data about the tasks to be solved by the AO, the vagueness is fundamental [7].

Thus, the aggregation method is to provide the union in the same group marks on the AO, with the highest degree of similarity to the coordinates and characteristics of movement and having a consistent signs.

In this case the main problem is keeping all of this information in determining the membership functions.

The most appropriate way to resolve this problem is to separate the definition of membership functions for each of the characteristics.

The main feature of the grouping is the spatial proximity data on air targets. Speed characteristics and indicative of the information it is advisable to refer to limitations.

Thus, the above considerations make it possible to formalize a task to achieve clearly defined goals and clear when the fuzzy constraints.

Let $X$ - is a universal set of alternatives, it is the universal set of all aggregation options. Fuzzy purpose in $X$. It is a fuzzy subset $X$, which will be denoted $X_{k}^{B}$, that is fuzzy subset formed groups. We describe the a fuzzy goal of membership function $\mu_{B k}: X \rightarrow[0,1]$. Limits define the set of feasible alternatives, and also describes the subsets of the set $X$.

A subset of speed limits is unclear, and is described by the membership function $\mu_{v}: X \rightarrow[0,1]$.

A subset of consistent signs of a clear and describes the membership function takes only two values $\mu_{p}: X \rightarrow 0$, if signs are contradictory and $\mu_{p}: X \rightarrow 1$, if the symptoms are consistent in terms of the combination of objects in the same group.

Then the fuzzy solution to the problem is to achieve the fuzzy intersection of fuzzy sets objectives and constraints, and accessories-making function has the form

$$
\mu_{B}(x)=\min \left\{\mu_{B k}(x), \mu_{v}(x), \mu_{p}(x)\right\} .
$$

The fuzziness of the solution is a consequence of the very vagueness of the original problem.

The set of admissible alternatives is determined using a clear limitation on the consistency of signs and speed limits. It builds the corresponding ratio of similarity

$$
R_{M}^{B}=\left\{\left(x_{B}, y_{B}\right) /\left(x_{B}, y_{B}\right) \in X_{B} \times X_{B}, \mu_{B}\left(x_{B}, y_{B}\right)=[0,1]\right\} .
$$

From the perspective of combining $\mathrm{AO}$ in a well-known set of features are divided into the following classes [8]:

- conflicting signs;

- noncontradictory signs;

- signs prohibiting aggregation object.

Taking into account the classification conducted expression to evaluate the function of fuzzy subset restrictions on indicative information looks as follows 


$$
\mu_{P}\left(x_{B}, y_{B}\right)=\min \left\{\mu_{\text {OГП }}\left(x_{B}, y_{B}\right), \mu_{3}\left(x_{B}\right), \mu_{3}\left(y_{B}\right), \mu_{H}\left(x_{B}, y_{B}\right)\right\},
$$

where $\mu_{\text {ОГI }}\left(x_{B}, y_{B}\right)$ - membership function of fuzzy constraints on grounds of nationality; $\mu_{3}\left(x_{B}\right)$, $\mu_{3}\left(y_{B}\right)$ - membership function of the fuzzy limit signs prohibiting association of data objects $x_{6}, y_{6}$ into a group, respectively; $\mu_{H}\left(x_{B}, y_{B}\right)$ - membership function of fuzzy constraints on the consistency of the other signs.

The functions of fuzzy restrictions on indicative information is calculated as follows

$$
\mu_{\text {ОГП }}\left(x_{B}, y_{B}\right), \mu_{3}\left(x_{B}\right), \mu_{3}\left(y_{B}\right), \mu_{H}\left(x_{B}, y_{B}\right)=\left\{\begin{array}{l}
1, \text { if symptoms notcontradictory } \\
0, \text { if symptoms notcontradictory }
\end{array}\right.
$$

In view of the information indicative of a subset of acceptable alternatives looks as follows

$$
\mu_{B}\left(x_{B}, y_{B}\right)=\min \left\{\mu_{B k}\left(x_{B}, y_{B}\right), \mu_{P_{v}}\left(x_{B}, y_{B}\right)\right\} .
$$

Thus, the set of all AO marks held by coordinates aggregation and indicative of information, that is, classes are marked similarity of marks. For the final classification, ie to isolate stable over time groups of marks must take into account the speed limit [9].

Before the do this, you need to submit aggregate information in the form of non-intersecting subsets of classes and aggregated to determine a sign or representative - the standard for everyone. Why transform building relationships of similarity in fuzzy strict preference relation and distinguish it clearly non-dominated alternatives

$$
\mu_{B}^{H}\left(x_{B}\right)=1-\sup _{x_{B}, y_{B} \in X_{B}}\left[\mu_{B}\left(y_{B}, x_{B}\right)-\mu_{B}\left(x_{B}, y_{B}\right)\right],
$$

wher sup - the supremum on the set $X$.

Clarification obtained classifications will hold given the fuzzy limit speed

$$
\mu_{B}\left(x_{B}, y_{B}\right)=\min \left\{\mu_{B}^{H}\left(x_{B}, y_{B}\right), \mu_{V}\left(x_{B}, y_{B}\right)\right\} .
$$

Moreover, the membership function of the fuzzy speed limit is calculated by the expression

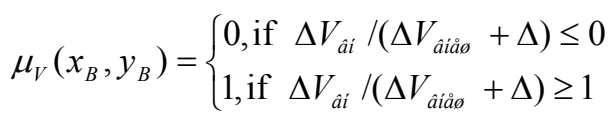

wher $\Delta V_{\text {вн }}=V_{x}-V_{y}$ - the speed difference between the constituent groups, $\Delta V_{\text {внеи }}=V_{x}-V_{э с}$ the difference between the velocities of the components of this group and the nearest adjacent component.

Defined in this way solution can be regarded as not clearly defined instructions, the execution of which will ensure the achievement of the goal fuzzy. The fuzziness of the solution is a consequence of the very vagueness of the original problem. In this representation of the solution is the uncertainty associated with the method of execution of such a fuzzy instructions, t. e. so, which alternative to choose. The most appropriate way to resolve the uncertainty of the solution is to choose the alternative that has the highest degree of fuzzy decision, that is an alternative to realizing [10]

$$
\begin{gathered}
\max _{x \in X} \mu_{B}(x)=\max _{x \in X} \min \left\{\mu_{B}^{H}\left(x_{B}, y_{B}\right), \mu_{V}\left(x_{B}, y_{B}\right)\right\} . \\
-477-
\end{gathered}
$$


Thus, the method of aggregating information on air situation, providing the minimization of losses in terms of information overload, the transmission channel of exchange and meeting the information requirements of consumers for its quality, consists:

- in the formation of fuzzy relation on the set marks similarity runs air targets and the definition of fuzzy defined goals;

- to transform the fuzzy relation matrix of similarity, with selected it based on clear restrictions on the information indicative of subsets of groups, fuzzy strict preference relation and allocation it is clearly non-dominated alternatives;

- in clarifying existing groups based on fuzzy limit speed and forming a subset of valid alternatives;

- in resolving the uncertainty of the solution by selecting the alternative, having the maximum degree of membership fuzzy decision.

The method of presentation of the data is similar to the interference regions developed method. The differences are in part indicative of a lack of information and speed limit. That is, data aggregation method on the areas of uncompensated of interference consists [10]:

- in the formation of fuzzy relation on the set marks similarity runs aerial objects and marks the space-extended regions of interference and the definition of fuzzy defined goals;

- in the transformation fuzzy relation matrix of similarity, with selected subsets marks areas of interference in relation fuzzy strict preference and allocation it is clearly non-dominated alternatives;

- resolving uncertainty of the solution by selecting the alternative, having the maximum degree of membership fuzzy decision.

\section{Conclusion}

Further, depending on the requirements of the user information (Data Link interacting CAE), data on the selected group AO can be represented as follows::

in the absence of information overload

- marks as a group of of their characteristics and features of the aggregated characteristic (reference) group and generalized characteristics in the absolute coordinate system;

with signs of information overload

- marks as a group of of their characteristics and features of the aggregated characteristic (reference) group and generalized characteristics relative to a coordinate system with the center coordinates coinciding with the reference coordinates;

- as a group of of coordinate marks aggregated feature (reference automaton) group and generalized characteristics relative to a coordinate system with the center coordinates coinciding with the reference coordinates downscaling (compression) of the coordinate axes several times;

- as a reference automaton and generalized characteristics of the group (spatially extended) air facility.

Of course, the implementation of the method directly in the form of an algorithm requires sufficient computing resources. Therefore, when developing the algorithm it implements necessary to carry out a preliminary assessment of the needs of computing resources. 


\section{References}

[1] Семин М.В. Проектирование на основе модульного принципа автоматизирванных информационных систем освоения эрготехнических комплексов. Эффективность автоматизированных систем управления авиацией, систем связи и РТО ВВС. Ногинск, 2012, 275 c. [Semin M.V. Design based on the modular principle of automated information systems development of ergotechnnical complexes. The effectiveness of automated control systems for aircraft, communication systems, and RTO's air force. Noginsk, 2012, 275 p. (in Russian)]

[2] Семин М.В., Потапов А.Н. Структура построения информационной математической модели эрготехнического объекта управления. Эффективность автоматизированных систем управления авиачией, систем связи и РТО ВВС. Ногинск, 2012, 275 c. [Semin M.V., Potapov A.N. Structure information of the mathematical model ergo technical object management. The effectiveness of automated control systems for aircraft, communication systems, and RTO's air force. Noginsk, 2012, 275 p. (in Russian)]

[3] Семин М.В., Потапов А.Н. Анализ особенностей отображения воздушной обстановки в информационной системе сложной иерархической АСУ. Вестник Военной академии воздушнокосмической обороны, 2013, 3 [Semin M.V., Potapov A.N. The analysis of peculiarities of display of air situation information system in a complex hierarchical ACS. Vestnik Voennoj akademii vozdushnokosmicheskoj oborony, 2013, 3. (in Russian)]

[4] Семин М.В. Анализ требований потребителей к информации о воздушной обстановке, циркулирующей в сложной иерархической автоматизированной системе управления. Всерос. науч.-техн. конф. «Теоретические и практические проблемы развития и совершенствования автоматизированных систем управления военного назначения». 29-30 октября 2013 г. СПб.: ВКА им. А.Ф.Можайского, 2013. 384 c. [Semin M.V. Analysis of customer requirements to the information on the air situation, circulating in complex hierarchical computer-aided control system. Teoreticheskie $i$ prikladnye problemy razvitija i sovershenstvovanija avtomatizirovanny sistem upravlenija voennogo naznachenija. 29-30 oktjabrja 2013 g. St. Petersburg, VKA im. A.F. Mozhajskogo. 2013, 384 p. (in Russian)]

[5] Семин М.В., Потапов А.Н. Анализ информационной подсистемы сложной иерархической автоматизированной системы управления с использованием теоретико-множественного подхода. Всерос. науч.-техн. конф. «Теоретические и практические проблемы развития и совершенствования автоматизированных систем управления военного назначения». 29-30 октября 2013 г. СПб.: ВКА им. А.Ф.Можайского, 2013. 384 с. [Semin M.V., Potapov A.N. The analysis of the information subsystem of complex hierarchical automated control system, using set-theoretic approach. Teoreticheskie i prikladnye problemy razvitija i sovershenstvovanija avtomatizirovannyh sistem upravlenija voennogo naznachenija. 29-30 oktjabrja 2013 g. . St. Petersburg, VKA im. A.F. Mozhajskogo, 2013, 384 p. (in Russian)]

[6] Семин М.В., Потапов А.Н. Обоснование подхода к разработке метода представления информации о воздушной обстановке для обмена в сложной иерархической структуре автоматизированной системы управления. Всерос. науч.-практ. конф. «Академические Жуковские чтения» 20-21 ноября 2013 г.. Воронеж, 2014, 180 с. [Semin M.V., Potapov A.N. The rationale for the approach to developing a method of presenting information on the air situation to share in the complex hierarchical structure of the automated control system. Akademicheskie Zhukovskie 
chtenija, 20-21 nojabrja 2013. Voronezh, VUNC VVS «VVA im. prof. N.E.Zhukovskogo i Ju.A. Gagarina», 2014, 180 p. (in Russian)]

[7] Семин М.В., Потапов А.Н., Кондратьева О.М. Агрегирование информации о воздушной обстановке для выдачи в каналы передачи данных. Материалы междунар. науч.-метод. конф. «Охрана. Безопасность. Связь - 2013» 28 ноября 2013 г. Воронеж, Воронежский ин-т МВД России, 2014, 317 с. [Semin M.V., Potapov A.N., Kondrat'eva O.M. The aggregation of information on the air situation for the issuance of the data transfer channels. Ohrana, Bezopasnost', Svjaz' - 2013», 28 nojabrja 2013 g. Voronezh: Voronezhskij institut MVD Rossii, 2014, 317 p. (in Russian)]

[8]Семин М.В.,Потапов А.Н.Оценкареализуемостиоптимальногоалгоритмапредставления информации в сложной иерархической автоматизированной системе управления. Материалы 43 военно-науч. конф. «Проблемы применения войск (сил) воздушно-космической обороны на современном этапе развития ВС РФ». 27-28 марта 2014 г. Тверь, ВА ВКО им. Г.К.Жукова, 2014. 392 c. [Semin M.V., Potapov A.N. Assessment of the feasibility of the optimal algorithm of information representation in complex hierarchical computer-aided control system. Problemy primenenija vojsk (sil) vozdushno-kosmicheskoj oborony na sovremennom jetape razvitija VS RF, 27-28 marta $2014 \mathrm{~g}$. Tver', VA VKO im. G.K. Zhukova, 2014. 392 p. (in Russian)]

[9] Семин М.В., Потапов А.Н. К вопросу об агрегировании информации для выдачи в каналы передачи данных. Всерос. науч.-практ. конф. «Актуальные вопросы эксплуатации систем охраны и защищенных телекоммуникационных систем», 5 июня 2014 г. Воронеж, Воронежский ин-т МВД России, 2014, 243 с. [Semin M.V., Potapov A.N. To the question about the aggregation of information for granting data transmission channels. Aktual'nye voprosy jekspluatacii sistem ohrany $i$ zashhishhenny telekommunikacionnyh system, 5 ijunja 2014 g. Voronezh, Voronezhskij institut MVD Rossii, 2014, 243 p. (in Russian)]

[10] Семин М.В. Алгоритм обнаружения информационной перегрузки в иерархической автоматизированной системе управления. Вестник Военной академии воздушнокосмической обороны, 2015, 5 [Semin M.V. The algorithm of detection of information overload in a hierarchical automated system management. Vestnik Voennoj akademii vozdushno-kosmicheskoj oborony, 2015, 5 (in Russian)] 